\title{
Fusobacterium polysaccharolyticum sp.nov., a Gram-negative Rod from the Rumen that Produces Butyrate and Ferments Cellulose and Starch
}

\author{
By N. O. VAN GYLSWYK \\ National Chemical Research Laboratory, Council for Scientific and \\ Industrial Research, P.O. Box 395, Pretoria 0001, South Africa
}

(Received 27 April 1979)

\begin{abstract}
A new Gram-negative, non-sporulating, rod-shaped, anaerobic bacterium capable of fermenting cellulose and starch was isolated from the rumens of sheep fed supplemented maize stover diets. The organism fermented few carbohydrates, showing a preference for polysaccharides. The main acid products of carbohydrate fermentation were butyrate and formate. Acetate was utilized.
\end{abstract}

\section{INTRODUCTION}

The Gram-negative, non-sporulating, cellulolytic, rod-shaped bacteria that have been isolated most frequently from the rumen are Bacteroides succinogenes and Butyrivibrio fibrisolvens. Others that have been found on only one occasion include one that produces mainly acetate (Margherita \& Hungate, 1963) and one, also unnamed, that produces butyric acid (Leatherwood \& Sharma, 1972).

This paper describes some of the characteristics of three isolates of a novel Gramnegative, rod-shaped bacterium isolated from sheep rumens.

\section{METHODS}

Source of isolates. Isolates were obtained from roll-bottles containing cellulose agar inoculated with high dilutions of rumen ingesta from sheep (Mackie et al., 1978). The new bacterium was isolated from sheep A72 after it had been fed on a diet containing $13.7 \%$ maize grain and $67.5 \%$ maize stover for $7 \mathrm{~d}$, and again when the animal had been fed for $7 \mathrm{~d}$ on a diet containing $50.2 \%$ maize grain and $28.3 \%$ stover. Isolates were also obtained from sheep A18 on the first and seventh days of feeding the latter diet. The dilutions of rumen ingesta from which the bacterium was isolated were $10^{-6}$ and, in one case, $10^{-7}$. Three isolates, designated $\mathbf{B}, \mathbf{E}$ and $\mathrm{G}$, were obtained in pure culture after repeated culturing on cellulose agar and picking of colonies that produced zones of clearing.

Culture techniques. These, including procedures to obtain and maintain strictly anaerobic culture conditions, were as described by van Gylswyk \& Hoffman (1970).

Media. Except where otherwise stated, media contained $\left(\mathrm{g} \mathrm{l}^{-1}\right): \mathrm{K}_{2} \mathrm{HPO}_{4}, 0 \cdot 225 ; \mathrm{KH}_{2} \mathrm{PO}_{4}, 0.225 ; \mathrm{NaCl}$, $0.45 ;\left(\mathrm{NH}_{4}\right)_{2} \mathrm{SO}_{4}, 0.45 ; \mathrm{CaCl}_{2}$ (anhydrous), $0.045 ; \mathrm{MgSO}_{4} .7 \mathrm{H}_{2} \mathrm{O}, 0.09 ; \mathrm{NaHCO}_{3}, 6.37 ;$ cysteine. $\mathrm{HCl} . \mathrm{H}_{2} \mathrm{O}$, $0.25 ; \mathrm{Na}_{2} \mathrm{~S} .9 \mathrm{H}_{2} \mathrm{O}, 0.25$; cellobiose, 5 ; indigo carmine, 0.005 ; together with rumen fluid from sheep fed lucerne hay (partially clarified by centrifuging at $1500 \mathrm{~g}$ for $30 \mathrm{~min}$ ), $400 \mathrm{ml}$; the gas phase was $98 \% \mathrm{CO}_{2}$ and $2 \% \mathrm{H}_{2}$ (gases were purchased from Afrox Ltd, Industria West, Germiston, South Africa).

The cysteine and sulphide were prepared as a combined, concentrated solution under nitrogen, made alkaline before addition to the medium (medium 1). For the preparation of maintenance slopes, the concentration of the mineral nutrients was doubled and agar $\left(15 \mathrm{~g}^{-1}\right)$ and Difco Casitone $\left(5 \mathrm{~g}^{-1}\right)$ were added. Cultures were grown in this medium when tested for the ability to produce gas and catalase. The cellobiose concentration of medium 1 was reduced to $1 \mathrm{~g} \mathrm{l}^{-1}$ for culturing bacteria that were examined for the presence of flagella. For fermentation tests, the concentration of $\mathrm{NaHCO}_{3}$ in medium 1 was reduced to one-tenth and the gas phase was $88 \% \mathrm{~N}_{2}, 10 \% \mathrm{CO}_{2}$ and $2 \% \mathrm{H}_{2}$ (medium 2 ). Soluble sugars and other substances were added 
in filter-sterilized solution to heat-sterilized medium. Insoluble substrates were heat-sterilized together with the basal medium. Temperature tolerance tests were done in medium 2 containing cellobiose as energy source.

The reaction of the bacteria to oxygen was tested in medium 1 containing filter-sterilized rumen fluid and with resazurin $(1 \mathrm{mg})$ replacing indigo carmine. One batch of medium was used without modification. From three further batches the cysteine and sulphide were omitted. To two of these batches were added, under pressure, either 5 or $30 \mathrm{ml}$ sterile air per $28 \mathrm{ml} \mathrm{McCartney}$ bottle containing $5 \mathrm{ml}$ medium. Test media for indole and acetylmethylcarbinol production contained Difco Casitone $\left(20 \mathrm{~g}^{-1}\right)$ and Difco yeast extract $\left(10 \mathrm{~g}^{-1}\right)$ instead of rumen fluid and indigo carmine was omitted. A similar medium was used in the test for nitrate reduction but cysteine and sulphide were omitted and $\mathrm{KNO}_{3}\left(1 \mathrm{gl}^{-1}\right.$; in filter-sterilized concentrated solution) was added.

For $\mathrm{H}_{2} \mathrm{~S}$ production medium 1 was supplemented with BBL Trypticase $\left(15 \mathrm{~g} \mathrm{l}^{-1}\right)$ and ferric ammonium citrate $\left(0 \cdot 2 \mathrm{~g}^{-1}\right)$. The gelatin liquefaction test was conducted with medium 1 containing $4 \%(\mathrm{w} / \mathrm{v})$ gelatin. Media for studying the types and quantities of fermentation end-products contained either cellobiose or ball-milled Whatman no. 1 filter paper cellulose $\left(14.3 \mathrm{~g} \mathrm{l}^{-1}\right.$ in each case). For determining the $\mathrm{G}+\mathrm{C}$ content, bacteria were grown in medium containing $300 \mathrm{ml}$ rumen fluid (clarified by centrifuging at $12000 \mathrm{~g}$ for $1 \mathrm{~h}$ ) and the cysteine and sulphide were each reduced to $0.0625 \mathrm{~g}^{-1}$. The ability of the bacteria to grow in the absence of rumen fluid was tested in medium in which peptone (Parke, Davis \& Co.) and yeast extract (each $10 \mathrm{~g}^{-1}$ ) replaced rumen fluid.

A chemically defined medium containing mineral salts, trace elements, vitamins, purines, pyrimidines [components of groups of nutrients and their concentrations were essentially similar to those employed by Roché et al., (1973)], one-tenth of the usual concentration of $\mathrm{NaHCO}_{3}$ and a gas phase of $88 \% \mathrm{~N}_{2}, 10 \% \mathrm{CO}_{2}$ and $2 \% \mathrm{H}_{2}$ was tested for its ability to support growth.

All media had a pH of about 6.8 and were incubated at $38 \pm 1{ }^{\circ} \mathrm{C}$.

Identification tests. Growth in liquid media was usually assessed turbidimetrically. In the tests for temperature tolerance, ability to ferment different substrates and ability to grow in the chemically defined medium, a change in $\mathrm{pH}$ was taken as indicative of growth. For the gelatin liquefaction test, cultures were incubated for $24 \mathrm{~h}$ and 1 week and then kept at about $4{ }^{\circ} \mathrm{C}$ until the medium in uninoculated, but similarly incubated, control bottles had gelled. Production of catalase, acetylmethylcarbinol and indole was assessed as described by Cato $e t$ al. (1973). To determine whether nitrite was produced from nitrate, the test described by Conn (1951) using $\alpha$-naphthylamine was employed. Staining for spores was done according to Schaeffer \& Fulton (1933) and heat tests $\left(80^{\circ} \mathrm{C}, 10 \mathrm{~min}\right)$ for spores were as described by Cato et al. (1973). Hydrogen sulphide production was indicated by blackening of the medium. Gas production was assessed by making stabs in $28 \mathrm{ml}$ McCartney bottles containing $15 \mathrm{ml}$ medium (similar to that used for maintenance slopes) and checking for the splitting of agar after 24 and $48 \mathrm{~h}$.

Fermentation end-products were determined using 1 week-old cultures. Ethanol was determined enzymically (Bonnischen, 1962). Volatile and non-volatile acids were determined by gas-liquid chromatography according to Cato et al. (1973). Concentrations of the acids were estimated using external standards. For cellulose-containing cultures, residual cellulose was determined as follows. Cultures were centrifuged and the bacteria were dissolved in $1 \mathrm{M}-\mathrm{NaOH}$ for $15 \mathrm{~min}$. The cellulose was washed with $5 \mathrm{M}$-acetic acid and three times with deionized water, followed each time by centrifugation. The material was dried in vacuo at $65^{\circ} \mathrm{C}$ and weighed.

For determining $\mathrm{G}+\mathrm{C} \mathrm{mol} \%$, cells were lysed with sodium dodecyl sulphate according to the method of Marmur (1961). Highly polymerized DNA was isolated and purified by the method of Meyer \& Schleifer (1975) and base composition was estimated from the $A_{245} / A_{270}$ ratio by the method of Ulitzur (1972). DNA standards used for calibration were from Micrococcus lysodeikticus, calf thymus and salmon sperm (all from Sigma).

All identification tests were done at least twice.

\section{RESULTS}

\section{Colony morphology and growth in solid and liquid media}

After $3 \mathrm{~d}$ incubation, surface colonies on $0.5 \%$ cellobiose $/ 40 \%$ rumen fluid agar in roll-bottles were about $1 \mathrm{~mm}$ in diameter, whitish and translucent, and round with smooth edges and raised centres. Cultures grown for $4 \mathrm{~d}$ in roll-bottles with similar medium containing $1.2 \%$ filter paper cellulose instead of cellobiose produced well-defined zones of clearing, 2 to $3 \mathrm{~mm}$ in diameter, showing complete cellulolysis. Small, discreet, round colonies were present in the centres of the zones. The zones enlarged on longer incubation. 

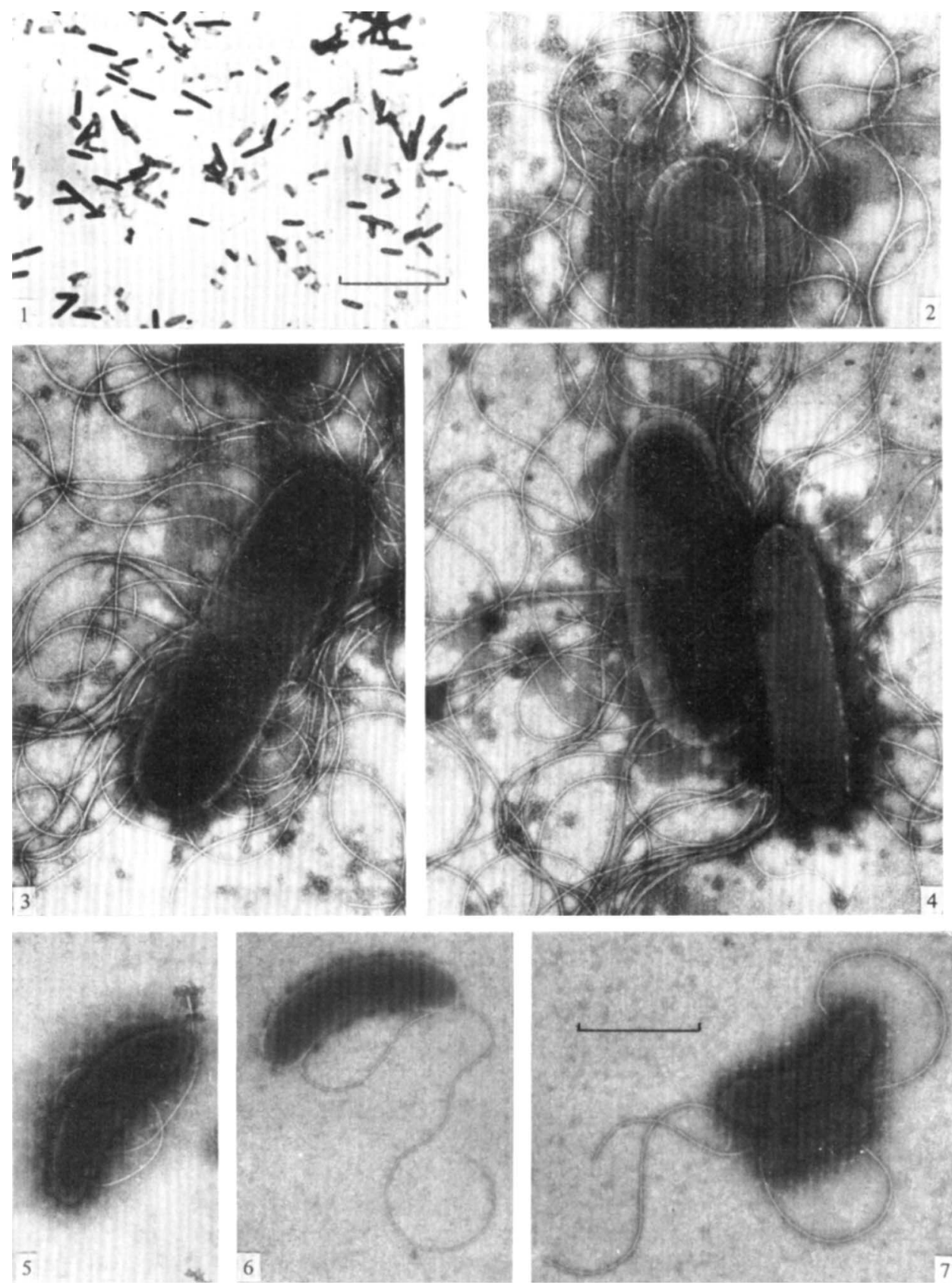

For Fig. 1, the bar marker represents $20 \mu \mathrm{m}$. For Figs 2 to 7, the bar marker (in Fig. 7) represents $1 \mu \mathrm{m}$.

Fig. 1. Gram-stained cells of Fusobacterium polysaccharolyticum.

Figs 2, 3 and 4. Transmission electron micrographs of cells of $F$. polysaccharolyticum isolate B after negative staining with phosphotungstic acid (3\%, pH 6).

Figs 5, 6 and 7. Transmission electron micrographs of cells of Butyrivibrio fibrisolvens isolate 12, stained as above. 
Table 1. Acid production from different carbohydrates by three isolates of a novel cellulolytic rumen bacterium

Final $\mathrm{pH}^{*}$ in poorly buffered medium

\begin{tabular}{|c|c|c|c|c|c|c|}
\hline \multirow[b]{2}{*}{ Carbohydrate } & \multicolumn{2}{|c|}{ Isolate $\mathbf{B}$} & \multicolumn{2}{|c|}{ Isolate $\mathrm{E}$} & \multicolumn{2}{|c|}{ Isolate $\mathrm{G}$} \\
\hline & $\begin{array}{c}\text { After } \\
48 \mathrm{~h}\end{array}$ & $\begin{array}{c}\text { After } \\
1 \text { week }\end{array}$ & $\begin{array}{l}\text { After } \\
48 \mathrm{~h}\end{array}$ & $\begin{array}{c}\text { After } \\
1 \text { week }\end{array}$ & $\begin{array}{r}\text { After } \\
48 \mathrm{~h}\end{array}$ & $\begin{array}{c}\text { After } \\
1 \text { week }\end{array}$ \\
\hline L-Arabinose & $6 \cdot 8$ & $5 \cdot 8$ & $6 \cdot 8$ & $5 \cdot 7$ & $6 \cdot 9$ & $5 \cdot 8$ \\
\hline Xylose & $6 \cdot 8$ & $5 \cdot 9$ & $6 \cdot 8$ & $5 \cdot 8$ & $6 \cdot 8$ & $6 \cdot 1$ \\
\hline Fructose & 6.9 & 5.9 & 6.8 & $6 \cdot 8$ & $6 \cdot 9$ & $6 \cdot 8$ \\
\hline Cellobiose & $5 \cdot 8$ & $5 \cdot 5$ & $5 \cdot 8$ & $5 \cdot 7$ & $5 \cdot 8$ & $5 \cdot 7$ \\
\hline Maltose & $6 \cdot 6$ & $5 \cdot 7$ & $6 \cdot 5$ & $5 \cdot 7$ & $6 \cdot 7$ & 5.9 \\
\hline Dextrin & $6 \cdot 0$ & $5 \cdot 9$ & $6 \cdot 1$ & $6 \cdot 0$ & $6 \cdot 1$ & $6 \cdot 1$ \\
\hline Pectin & 6.6 & 6.0 & $6 \cdot 6$ & $6 \cdot 5$ & $6 \cdot 7$ & $6 \cdot 5$ \\
\hline Starch & $5 \cdot 7$ & $5 \cdot 6$ & $5 \cdot 7$ & 5.6 & $5 \cdot 5$ & $5 \cdot 7$ \\
\hline Xylan & $5 \cdot 6$ & $5 \cdot 7$ & $5 \cdot 7$ & $5 \cdot 7$ & $5 \cdot 7$ & $5 \cdot 7$ \\
\hline
\end{tabular}

When an inoculum was placed on the surface of agar slopes containing rumen fluid and $1 \%$ cellulose, the cellulose was almost completely solubilized after $5 \mathrm{~d}$ incubation. Cellulolysis still occurred after many transfers of the organisms on cellobiose-containing medium, showing that the ability to solubilize cellulose is not easily lost. Growth on the surface of agar slopes appeared as a transparent mucous mass.

In liquid media, after initial active growth, a mucous sediment was formed, particularly in the case of isolate $\mathrm{G}$ which tended to produce a large amount of extracellular slime. This made the medium viscous and it was difficult to resuspend the sediment by shaking. On no occasion in any medium was pigment production observed.

\section{Morphology and Gram reaction}

There was some doubt as to whether the organisms were Gram-negative as they stained considerably darker than cells of Escherichia coli and Proteus vulgaris. Accordingly the three isolates, together with Streptococcus bovis, a Gram-positive organism, were stained in the usual way except that the counter stain (carbol fuchsin) was not applied. On microscopic examination it appeared that the cells of $S$. bovis became heavily stained whereas the cells of the new organisms remained unstained. It was concluded that the new isolates were Gram-negative but that they stained unusually intensely with the counter stain.

Bacteria grown for 16 to $24 \mathrm{~h}$ on 0.1 or $0.5 \%$ cellobiose/rumen fluid agar slopes and stained by Gram's method were seen as straight rods with rounded ends (Fig. 1), usually occurring singly, but chains and long cells were often observed in young cultures. Their width varied from 0.6 to $1.1 \mu \mathrm{m}$ and length from 2 to more than $15 \mu \mathrm{m}$ (typically, $0.8 \mu \mathrm{m}$ wide and 3 to $6 \mu \mathrm{m}$ long). In cellobiose/rumen fluid medium adjusted to $\mathrm{pH} 7 \cdot 2$, aseptate filaments, $50 \mu \mathrm{m}$ and more in length, were observed. Cells in older cultures lysed very readily, often swelling before disintegrating. The bacteria possessed many peritrichous flagella (Figs 2 to 4). Numerous tests for the presence of spores in different media all proved negative.

\section{Effects of oxygen, temperature and $\mathrm{pH}$ on growth}

The isolates were anaerobes in that they failed to grow in media under air. They grew well in media free of added oxygen irrespective of whether cysteine and sulphide were present. Medium free of these compounds appeared orange due to partially reduced resazurin. During growth of the bacteria this colour did not change and remained the same as that in uninoculated bottles indicating that the redox potential was not lowered significantly during growth. 
Table 2. Acids produced or utilized by three isolates of a novel cellulolytic rumen bacterium in media containing cellobiose or cellulose

The uninoculated medium contained [mmol $\left.(100 \mathrm{ml} \text { medium })^{-1}\right]$ : acetate, 4.5 ; propionate, 0.9 ; butyrate, 0.4 .

\begin{tabular}{|c|c|c|c|c|c|c|}
\hline \multirow[b]{3}{*}{ Acid } & \multicolumn{6}{|c|}{ Production $(+)$ or utilization $(-)$ of acid $\left[\mathrm{mmol}(100 \mathrm{ml} \text { medium })^{-1}\right.$ ] } \\
\hline & \multicolumn{2}{|c|}{ Isolate B } & \multicolumn{2}{|c|}{ Isolate $\mathrm{E}$} & \multicolumn{2}{|c|}{ Isolate $\mathrm{G}$} \\
\hline & Cellobiose & Cellulose & Cellobiose & Cellulose & Cellobiose & Cellulose \\
\hline Formate & $+3 \cdot 1$ & $+1 \cdot 3$ & $+4 \cdot 0$ & $+1 \cdot 8$ & +3.6 & $+1 \cdot 7$ \\
\hline Acetate & -0.7 & $-2 \cdot 3$ & $-0 \cdot 2$ & $-2 \cdot 5$ & $+0 \cdot 1$ & $-2 \cdot 5$ \\
\hline Propionate & $-0 \cdot 1$ & $-0 \cdot 1$ & $-0 \cdot 1$ & $-0 \cdot 1$ & -0.2 & $-0 \cdot 1$ \\
\hline Butyrate & $+2 \cdot 2$ & $+3 \cdot 0$ & $+2 \cdot 3$ & $+3 \cdot 2$ & $+1 \cdot 7$ & $+3 \cdot 1$ \\
\hline
\end{tabular}

None of the isolates grew at $22^{\circ} \mathrm{C}\left(\mathrm{pH}\right.$ unchanged). After $4 \mathrm{~d}$ at $30^{\circ} \mathrm{C}$ the final $\mathrm{pH}$ was between 5.7 and 5.8 , the same as at $38^{\circ} \mathrm{C}$. At $45^{\circ} \mathrm{C}$ the final pH was 6.4 and 6.1 for isolates $\mathrm{B}$ and $\mathrm{E}$, respectively, while isolate $\mathrm{G}$ did not grow.

The optimum $\mathrm{pH}$ for growth was about 6.8 (A. Kistner, personal communication).

\section{Fermentation}

Substrates fermented by the three isolates are given in Table 1. Media containing Larabinose or xylose did not show a fall in $\mathrm{pH}$ after $48 \mathrm{~h}$ but an appreciable decrease was noted after 1 week. Fructose was fermented only by isolate B after 1 week. Only a slight fall in $\mathrm{pH}(0.4 \mathrm{pH}$ units or less) after $48 \mathrm{~h}$ and a significant decrease ( $1 \mathrm{pH}$ unit or more) after 1 week was observed with medium containing maltose. Pectin was poorly fermented, only isolate B showing a decrease of about $0.9 \mathrm{pH}$ units after 1 week. The greatest consistent decrease in $\mathrm{pH}$ (more than $1 \mathrm{pH}$ unit) was found for cellobiose, starch and xylan. It appeared that the bacteria were utilizers of highly polymerized substrates common in ruminant feeds. Cellulose was also always vigorously attacked. No growth or fall in $\mathrm{pH}$ was noted in media containing galactose, glucose, glycerol, inositol, inulin, lactose, mannitol, mannose, raffinose, rhamnose, salicin, sodium DL-lactate, sucrose or trehalose.

The isolates produced gas, as shown by the splitting of agar, which was very pronounced after $48 \mathrm{~h}$. Only traces of ethanol were produced and a weakly positive reaction was obtained in the test for acetylmethylcarbinol for all three isolates after $5 \mathrm{~d}$ incubation. They did not produce lactate or succinate. The extent to which the isolates produced or utilized formic, acetic, propionic and butyric acids in media containing cellobiose or cellulose is shown in Table 2 . Formate and butyrate were the major products of fermentation. The difference in the amount of acetate utilized between media containing cellobiose and cellulose corresponded with the difference in butyrate production. The less butyrate was produced in cellobiose medium the more formate was produced in compensation. This was supported by results of calculations on the stoicheiometry of the reactions $\mathrm{CO}_{2} \rightarrow$ formate, and acetate $\rightarrow$ butyrate in terms of hydrogen equivalents required. Quantitative differences in end-products found with the two substrates were probably due to differences in growth and fermentation rates, suggesting that cellulolysis may be growth rate-limiting.

In cellulose medium, isolates $\mathrm{B}$ and $\mathrm{E}$ solubilized $75 \%$ of the substrate, equivalent to $6.6 \mathrm{mmol}$ glucose (isolate $\mathrm{G}$ was not examined). Of this, less than $30 \%$ appeared in butyrate (after subtracting butyrate derived from acetate in the medium). It is possible that a large proportion of the solubilized cellulose was not metabolized.

\section{Nutritional and other characteristics}

The isolates grew in peptone/yeast extract medium free of rumen fluid only if a fermentable carbohydrate was added. Growth was stimulated by acetate. Moderate growth occurred 
in the chemically defined medium (final pH $6 \cdot 1$ for isolates $\mathrm{B}$ and $\mathrm{E}$ and 6.4 for isolate $\mathrm{G}$ ). No growth occurred on this medium when $\mathrm{CO}_{2}$ and bicarbonate were omitted (gas phase was $98 \% \mathrm{~N}_{2}$ and $2 \% \mathrm{H}_{2}$ ). Growth improved when peptone and yeast extract were added (final pH $5 \cdot 8$ to 5.9 ). Addition of $30 \%$ rumen fluid had an even greater stimulatory effect as shown by a much greater cell density (final $\mathrm{pH}, 5 \cdot 5$ to $5 \cdot 7$ ).

Catalase, indole and $\mathrm{H}_{2} \mathrm{~S}$ were not produced; gelatin was not liquefied and nitrite was not detected 1 and $5 \mathrm{~d}$ after inoculation. Semi-quantitative tests for nitrate indicated that it had not disappeared during growth.

The $\mathrm{G}+\mathrm{C}$ mol $\%$ for isolate B was $41 \cdot 6$, compared with $41 \cdot 4$ for Butyrivibrio fibrisolvens 12 (described by van Gylswyk \& Roché, 1970) and 50.9 for Eubacterium cellulosolvens 6 (described by van Gylswyk \& Hoffman, 1970). Leatherwood \& Sharma (1972) obtained a value of $41 \cdot 2$ for $B$. fibrisolvens A38.

\section{DISCUSSION}

The new isolates resemble $B$. fibrisolvens and the bacterium described by Leatherwood \& Sharma (1972) in that they are all Gram-negative, anaerobic, non-sporulating rods from the rumen that produce butyric acid and therefore appear to be physiologically similar. They resemble Butyrivibrio in $\mathrm{G}+\mathrm{C}$ content and differ from it in morphology and type of flagellation (compare Figs 2 to 4 with Figs 5 to 7). They differ morphologically from the bacterium isolated by Leatherwood \& Sharma (1972) in that the latter possessed no flagella, occurred in long twisted chains and had a G+C content of $36.3 \mathrm{~mol} \%$.

According to Bergey's Manual of Determinative Bacteriology (Buchanan \& Gibbons, 1974), the new isolates would fall in the genus Fusobacterium (Knorr) in that they are motile with peritrichous flagella, Gram-negative anaerobes which produce butyric acid from carbohydrate and have a $\mathrm{pH}$ optimum close to 7 . The $\mathrm{G}+\mathrm{C}$ content of the DNA in most species of fusobacteria examined ranges from 26 to $34 \mathrm{~mol} \%$ but one species, F. symbiosum, was found to have a $\mathrm{G}+\mathrm{C}$ mol $\%$ of 48 (Buchanan \& Gibbons, 1974). The $\mathrm{G}+\mathrm{C} \mathrm{mol} \mathrm{\%} \mathrm{of}$ the new bacterium would not exclude it from the genus Fusobacterium; however, the novel isolates differ from all the species described under this genus. An appropriate specific epithet for the new bacterium would be polysaccharolyticum in view of its assumed function in the rumen, i.e. that of degrading polymerized carbohydrates such as cellulose, xylan (hemicellulose) and starch. Isolate B is the type strain and has been deposited in the American Type Culture Collection (accession number ATCC 33142).

The occurrence of $F$. polysaccharolyticum in the rumens of sheep fed supplemented maize stover diets was not merely sporadic as bacteria of this type were found in the rumens of two sheep, when fed different levels of grain on different occasions. Isolates were obtained from random roll-bottles used when making counts of cellulolytic bacteria and it is possible that a search for this organism may have revealed a more general occurrence in the rumen ingesta of different sheep. The dilutions of ingesta in medium from which the organisms were isolated indicate that they occurred at levels of at least $10^{6}$ per $\mathrm{g}$ ingesta.

The author wishes to thank Dr F. M. C. Gilchrist for providing the roll-bottles from which the bacteria were isolated, Miss S. Pritchard for obtaining the isolates in pure culture and Mrs A. E. van der Walt for technical assistance. Thanks are also due to Mr H. J. Els of the Veterinary Research Institute, Onderstepoort, South Africa, for the electron microscopy and Mr J. Soley of the Veterinary Faculty of the University of Pretoria, for his help in preparing the photographs. 


\section{REFERENCES}

BonNichSen, R. (1962). Ethanol. Determination with alcohol dehydrogenase and DPN. In Methods of Enzymatic Analysis. Edited by H. U. Bergmeyer. New York: Academic Press.

Buchanan, R. E. \& Gibbons, N. E. (editors) (1974). Bergey's Manual of Determinative Bacteriology, 8th edn. Baltimore: Williams \& Wilkins.

Cato, E. P., Cummins, C. S., Johnson, J. L., Smibert, R. M., SMITh, L. D. S. \& Wilkins, T. D. (1973). In Anaerobe Laboratory Manual, 2nd edn. Edited by L. V. Holdeman \& W. E. C. Moore. Blacksburg, Virginia: Virginia Polytechnic Institute and State University.

ConN, H. J. (1951). Routine tests for the descriptive chart. Morphological and biochemical. Leaflet V. In Manual of Methods for Pure Culture Study of Bacteria, 12th edn. Edited by Committee of Bacteriological Technic of the Society of American Bacteriologists. Geneva, N.Y.: Biotech Publications.

van Gylswyk, N. O. \& Hoffman, J. P. L. (1970). Characteristics of cellulolytic cillobacteria from the rumens of sheep fed teff (Eragrostis tef) hay diets. Journal of General Microbiology 60, 381-386.

vaN GyLsWyK, N. O. \& RochÉ, C. E. G. (1970). Characteristics of Ruminococcus and cellulolytic Butyrivibrio species from the rumens of sheep fed differently supplemented teff (Eragrostis tef) hay diets. Journal of General Microbiology 64, 11-17.

Leatherwood, J. M. \& Sharma, M. P. (1972). Novel anaerobic cellulolytic bacterium. Journal of Bacteriology 110, 751-753.
Mackie, R. I., Gilchrist, F. M. C., Robberts, A. M., Hannah, P. E. \& Schwartz, H. M. (1978). Microbiological and chemical changes in the rumen during stepwise adaptation of sheep to high concentrate diets. Journal of Agricultural Science 90, 241-254.

Margherita, S. S. \& Hungate, R. E. (1963). Serological analysis of Butyrivibrio from the bovine rumen. Journal of Bacteriology 86, 855-860.

MARMUR, J. (1961). A procedure for the isolation of deoxyribonucleic acid from micro-organisms. Journal of Molecular Biology 3, 208-218.

Meyer, S. A. \& SCHLeIfER, K. H. (1975). Rapid procedure for the approximate determination of the deoxyribonucleic acid base composition of micrococci, staphylococci, and other bacteria. International Journal of Systematic Bacteriology 25, 383-385.

Roché, C. E. G., Albertyn, H., van Gylswyk, N. O. \& KistNer, A. (1973). The growth response of cellulolytic acetate-utilizing and acetate-producing butyrivibrios to volatile fatty acids and other nutrients. Journal of General Microbiology 78, 253-260.

Schaeffer, A. B. \& Fulton, McD. (1933). A simplified method of staining endospores. Science $77,194$.

UlitzUR, S. (1972). Rapid determination of DNA base composition by ultraviolet spectroscopy. Biochimica et biophysica acta 272, 1-11. 